The Racialisation of British Policing 
Also by Simon Holdaway

THE BRITISH POLICE (editor)

INSIDE THE BRITISH POLICE: A Force at Work

CRIME AND DELIVERANCE

RECRUITING A MULTI-RACIAL POLICE FORCE 


\section{The Racialisation of British Policing}

Simon Holdaway 
Houndmills, Basingstoke, Hampshire RG21 6XS

and London

Companies and representatives

throughout the world

A catalogue record for this book is available

from the British Library.

ISBN 978-0-333-56395-3

ISBN 978-1-349-24481-2 (eBook)

DOI 10.1007/978-1-349-24481-2

First published in the United States of America 1996 by

ST. MARTIN'S PRESS, INC.,

Scholarly and Reference Division,

175 Fifth Avenue,

New York, N.Y. 10010

ISBN 978-0-312-12939-2

Library of Congress Cataloging-in-Publication Data

Holdaway, Simon.

The racialisation of British policing / Simon Holdaway.

p. $\mathrm{cm}$.

Includes bibliographical references and index.

ISBN 978-0-312-12939-2 (cloth)

1. Police-Great Britain. 2. Discrimination in law enforcement-Great Britain. 3. Great Britain-Race relations. I. Title.

HV8195.A2H65 1996

363.2'0941-dc20

\section{Copyright $\odot$ Simon Holdaway 1996}

All rights reserved. No reproduction, copy or transmission of this publication may be made without written permission.

No paragraph of this publication may be reproduced, copied or transmitted save with written permission or in accordance with the provisions of the Copyright, Designs and Patents Act 1988, or under the terms of any licence permitting limited copying issued by the Copyright Licensing Agency, 90 Tottenham Court Road, London WIP 9HE.

Any person who does any unauthorised act in relation to this publication may be liable to criminal prosecution and civil claims for damages.

$\begin{array}{rrrrrrrrrr}10 & 9 & 8 & 7 & 6 & 5 & 4 & 3 & 2 & 1\end{array}$

$\begin{array}{llllllllll}05 & 04 & 03 & 02 & 01 & 00 & 99 & 98 & 97 & 96\end{array}$




\section{Contents}

List of Tables vi

Preface vii

1 Thinking about 'race' 1

2 Victims of crime in Britain 25

3 Racial attack in Britain 45

4 The cultural mediation of 'race' - occupational cultures, crime and arrests

5 British police responses to riots

6 An enemy within - racialised relations within the British police

7 Emerging themes 178

Notes and References

Bibliography

Index 


\section{List of tables}

1 Proportion of incidents involving racial motivation: 1988 and 1992 BCS

2 Differential risks of victimisation: percent victimised once or more, by ethnic origin: 1988 and 1992 BCS

3 Recorded racial incidents in provincial forces in England and Wales 1984-8 


\section{Preface}

Robert Reiner suggested I might write this book in 1989, as one of a series he was editing, but before a contract could be issued his publisher had been the subject of a merger and the series was cancelled. The half written text stayed in a drawer until Frances Arnold from Macmillan visited my university department, scouting for manuscripts. I mentioned the fragment and the order was given to complete it! Catherine Gray at Macmillan finally saw the project to print. I am grateful to all of them for their important encouragement and advice. As the project progressed Marian Fitzgerald and Michael Banton read parts of the manuscript, making many helpful suggestions. Paul Rock's work has over the years provided me with more ideas than I can cope with. I want to recognise his contribution to my thinking. None of these people hold any responsibility for the finished text but I have benefited from their assistance. It may sound trite but Hilary, Ruth, Ben, David and Peter - my family - have to be mentioned, with love.

I have been researching and writing about the police for a considerable number of years, longer than I care to remember. Throughout this time my interest has been sustained in relationships between the police and minority ethnic groups. This takes me further back, to my years as a police officer. Throughout my police service I worked in areas of large minority ethnic settlement and have seen at first hand the ways in which ideas about 'race' mould police work. I have also had opportunities in recent years to research racialised relations within the police and listen to many black and Asian officers talk about their experience of police employment. This book brings together many ideas I have gathered as my research has progressed and I hope to have written a fairly comprehensive introduction to the sociological study of relations between the police and minority ethnic groups that will help students gain insight into their complexities. It is also my hope that the occasional new idea is found in the pages that follow.

My university work brings me into contact with professionals working in criminal justice institutions, undergraduates and 
probation and social work trainees. Many students come to the study of race issues within what we inappropriately call the 'criminal justice system' equipped with one, undefined concept - 'racism'. They are all too often unwilling to look carefully at the research evidence or reflect on their ideas. Clarification of concepts is resisted. In this book I hope to prompt readers to ask some questions about the adequacy of thinking in 'isms' and to reflect more carefully on the available evidence about aspects of racialised relations. I also hope to suggest tactfully that criminologists should consider more fully the vital contribution sociological theory can make to their subject.

One reason for this all too easy stance taken by students and some academics is the desire to see more harmonious relations between minority and majority populations in contemporary Britain. This is obviously good and to be encouraged but I hope it does not sound too middle-aged (and stereotypical) to say that it is based on a woefully simplistic understanding of the way in which social phenomena are constructed and sustained within organisational and cultural settings. This book tries to be relevant to policy reform, working from a framework of analysis that retains 'race' precisely within the organisational and cultural structures of policing. Once these contexts are taken into account it becomes rather more difficult to propose effective policy reform.

One hot summer's day in the 1970s I took two of my children to Alton Towers. We joined a long queue for the Log Flume, a ride in boats along rough water. As we got near the entrance to the ride, to one side and above, boats full of expectant occupants began their voyage along a waterfilled channel. Two Asian families waited in front of us. As a boat passed by water was splashed over them and the occupants, four youths, none over 13 years of age, shouted 'Pakis'. The families just continued waiting. This incident has remained in my memory. Waiting is frustrating, all the more so when accompanied by personal abuse. Was this a routine happening that could be accommodated within the daily round? How could the abusive kids be so vile? Why is it like this? How can we change the world?

Other incidents come to mind: to the elderly Asian man reporting to me in 1970 a 'kicking' he had received at the hands of skinheads near to Brick Lane; the gaze of many black people living in Notting Hill as I patrolled their streets; the racial jokes and remarks told by 
Preface ix

officers; to the dilemmas of officers wanting to challenge and change the police; the wonderful sense of pride and solidarity expressed by officers launching their Black Police Association. Motivation to keep researching and writing are affected by personal experiences like these. Dare I remember these people and write the book for them as much as for anyone else? We need change.

SIMON HOLDAWAY

Every effort has been made to trace all the copyright-holders, but if any have been inadvertently overlooked the publishers will be pleased to make the necessary arrangement at the first opportunity. 